\title{
ISTORINIAI PRIEMIESČIAI SENAMIESČIŲ STRUKTŪROJE
}

\author{
Dalia Dijokienè \\ Urbanistikos katedra, Vilniaus Gedimino technikos universitetas, \\ Pylimo g. 26/Trakųg. 1, LT-01132Vilnius, Lietuva, el.paštas.dijokai@takas.lt
}

Iteikta 20090330

Santrauka. Atkreipiamas dèmesys ị tai, kad daugumos saugomų Lietuvos senamiesčių ribos yra juridinès, o ne struktūrinès - tai sukelia nemažai problemų realizuojant šių teritorijų apsaugą. Apibrěžiamos sąvokos: istorinis miestas, senamiestis, istorinis miesto branduolys, istorinis priemiestis. Apibendrintai aptariami Vilniaus, Kauno, Klaipėdos ir Kėdainių istorinių priemiesčių, esančių senamiesčiuose, urbanistiniai ypatumai - plano, užstatymo ir tūrinès erdvinès kompozicijos savitumai. Iliustracijose grafiškai išskiriamos senamiesčių sudètinès dalys - istorinis miesto branduolys ir istoriniai priemiesčiai.

Reikšminiai žodžiai: istorinis miestas, istorinis priemiestis, senamiestis, istorinis miesto branduolys, urbanistikos paveldas, kultūros paveldas.

\section{Ivadas}

„Europos miestai iškilo kartu su pačia Europa ir tam tikra prasme sukūrè šį regioną. <...> Europos miesto istorija ir pačios Europos istorija didžia dalimi yra ta pati, neatsiejama ir gerai ł̇amžinta" (Benevolo 1998). Būtų sunku ịsivaizduoti Europos miestą be senamiesčio. Dauguma Lietuvos miestų ir miestelių taip pat turi kelis šimtmečius menančius istorinius centrus. Nors nekilnojamojo kultūros paveldo apsaugos raidoje urbanistikos paveldo objektai pradèti saugoti vèliausiai (Miškinis 2005), dèl pasišventusių urbanistikos paveldo tyrejjų Lietuvoje turime ne vieną dešimtị saugomų šių objektų. Tik dažną kartą mūsų šalyje kultūros paveldo vertybiu apsauga apsiriboja begaliniais draudimais, keliančiais alergiją, bejëgiškumą arba priešiškumą, o paveldo vertybès pamažu nyksta pačios ar patyliukais naikinamos. Nemažai problemų kyla dèl to, kad urbanistikos paveldo vertybių ir jų apsaugos zonų ribos yra nubrèžtos ignoruojant miesto morfologinę specifiką, nekreipiant dèmesio ị istoriškai susiklosčiusias miesto dalių ribas. Daugelio Lietuvos miestų saugomų senamiesčiu ribos yra tik juridinès, bet ne struktūrinès (Vyšniūnas 2006).

Sumaištị kelia ir specialistų vartojami skirtingi terminai, apibūdinantys urbanistikos paveldo vertybes. Kad nekiltų neaiškumų, straipsnyje vartojami pagrindiniai terminai yra apibrèžti 1 lentelejje, jų nusakomas teritorijas iliustruoja 1 pav. (Vilniaus miesto pavyzdžiu).

Senamiesčių urbanistinį audinị laiko tèkmè dèliojo tarsi mozaiką - istoriniai priemiesčiai, reprezentuojantys skirtingai besiformavusias dabartinio miesto dalis, papildè miesto paveikslą. Priemiesčių reiškinys yra beveik toks pat senas kaip ir patys miestai. Ten, kur buvo griežtas suvaržymas, būtinai buvo ir prasiveržimas. Žmonès, gyvenę tankiuose kvartaluose, turejo taikstytis su įvairiais būties apribojimais arba bègti iš miestų. Tiek, kiek miestai buvo klestintys, tiek jie viliojo periferijos gyventojus, norinčius pasinaudoti bendruomeninio gyvenimo privalumais (Kostof 2004). Taigi istoriniai miesty centrai formavosi kaip dviejų pasaulių, dviejų skirtingų urbanistinių struktūrų (miestiškos ir priemiestinès) kompozicija. Tiesa, daugelis Europos miestų istorinių priemiesčių nebeturi šios teritorijos sunyko pačios ar buvo sugriautos karų, jų vietoje išaugo šių dienų miesto struktūros, parkai. Lietuvoje istoriniai miestu branduoliai vis dar apsupti istoriniu priemiesčiu.

Autore yra nagrinejjusi ir ne kartą rašiusi apie istorinių priemiesčių kilmę, raidą, vertybes (Dijokienè 2006a, 2006b, 2007). Šiame straipsnyje yra aptariami susiklostę 
1 lentelè. Vartojami terminai

Table 1. Concepts used in the paper

\begin{tabular}{|c|c|}
\hline Terminas & Apibrèžimas \\
\hline Istorinis miestas & $\begin{array}{l}\text { Toks urbanistinis darinys, kuris formavosi nuo pat savo kilmès pradžios iki Naujujuy amžiu ir } \\
\text { turëjo visas miestui būdingas funkcijas. Šis terminas apibūdina pačius miestus, bet neapibrè- } \\
\text { žia teritorijos. }\end{array}$ \\
\hline Senamiestis & $\begin{array}{l}\text { Seniausia istorinio miesto zona. Šis terminas nusako teritoriją. Kaip senamiesčio sinonimas dar } \\
\text { vartojamas terminas istorinis centras (terminas vartotas trečiajame Vilniaus senamiesčio rege- } \\
\text { neracijos projekte). }\end{array}$ \\
\hline $\begin{array}{l}\text { Istorinis miesto } \\
\text { branduolys }\end{array}$ & $\begin{array}{l}\text { Tai brandžiausia urbanistikos ir architektūros požiūriais istorinio miesto ir senamiesčio dalis. } \\
\text { Dažniausiai šią teritoriją ribodavo gynybiniai įtvirtinimai ar gamtinės kliūtys (buvo ir išimčių). }\end{array}$ \\
\hline Istorinis priemiestis & $\begin{array}{l}\text { Tos istorinio miesto teritorijos, kurios savo kilmės pradžioje buvo priemiesčiai. Jụ atsiradimas } \\
\text { sietinas su miesto atsiradimu. Tokios teritorijos formavosi iki XIX a. vidurio. Šis terminas buvo } \\
\text { vartojamas antrajame ir trečiajame Vilniaus senamiesčio regeneracijos projektuose (čia jie dar } \\
\text { vadinami viduramžiškais priemiesčiais). Pagal teritorinį išsidèstymą miesto branduolio atžvilgiu } \\
\text { straipsnio autorè išskiria arčiausiai miesto branduolio esančius istorinius priemiesčius ir labiau } \\
\text { nutolusius. Dabar šios teritorijos jau nebèra priemiesčiai, jos yra senamiesčiu arba istoriniu } \\
\text { miestu centru sudètinès dalys. }\end{array}$ \\
\hline
\end{tabular}

istorinių priemiesčių urbanistiniai ypatumai - analizuojami plano, užstatymo ir tūrinès erdvinés kompozicijos savitumai. Nagrinejami keturių Lietuvos miestų (Vilniaus, Kauno, Klaipèdos ir Kèdainių) istoriniai priemiesčiai, esantys senamiesčiuose. Vieni urbanistinès struktūros komponentai istoriniuose priemiesčiuose išliko nepakitę nuo savo formavimosi pradžios iki šių dienų (jų vertė yra didžiausia), kiti istorijos eigoje keitèsi, tačiau išlaikè daugelio epochų bruožus (jie irgi yra vertingi), o treti visai išnyko (kartu neteko ir urbanistinès-architektūrinès vertès). Kiekvienas iš minètų urbanistinès struktūros komponentų galètų būti detalesnių studijų tyrimo objektu. Šis straipsnis yra daugiau apžvalginis ir nubrèžiantis gaires tolesniems tyrimas.

Dar vienas šio straipsnio tikslas yra noras atkreipti kultūros paveldo vertybių apsaugos specialistų démesị i tai, kad dideles urbanistikos paveldo vertybių teritorijas vertètų skaidyti į mažesnius struktūrinius vienetus, įvardinti jų ypatumus ir siūlyti skirtingus apsaugos reglamentus. Tiesa, tokị bandymą galima rasti Vilniaus senamiesčio apsaugos reglamente (2003 m.) čia senamiestis dalinamas i 10 zonų (Vilniaus ... 2003). Straipsnio autorè siūlytų preciziškesnị, smulkesnị teritorijos skaidymą.

\section{Plano savitumai}

Nagrinètų Lietuvos miestų senamiesčių urbanistinès struktūros yra labai ịvairios ir gerokai skiriasi viena nuo kitos. Vilnius yra natūraliai susiklosčiusio miesto organizmo pavyzdys. Plano struktūroje dominuoja radialinis gatvių išsidèstymas. Kaunas ir Klaipèda buvo formuoti pagal stačiakampi planą, tiesa, taikant skirtingus miestų planavimo principus. Kèdainių istorinị branduolị sudaro tiek savaimingai besiklosčiusi miesto dalis, tiek planingai formuoti priemiesčiai (ar atskiros miesto dalys). Šių keturių miestų istoriniuose priemiesčiuose galima sutikti visus plano struktūros tipus: linijinị, radialinị, stačiakampị ir mišrų. Tai iliustruoja 2 lentelè. Daugelyje priemiesčių plano struktūros turi kelių tipų bruožus, tik vienas kitas priemiestis yra išskirtinai vieno plano tipo atstovas pvz.: Užupis (Vilniuje) yra radialinio plano, Žvèrynas (Vilniuje) ir Vilijampolè (Kaune) yra stačiakampio plano. Priemiesčiai 2 lentelèje priskirti dominuojančiam plano struktūros tipui.

Istoriniai priemiesčiai, susilieję su miesto branduoliu, papildè plano struktūrą. Vilniaus, Kauno, Klaipèdos ir Kèdainių senamiesčių gatvių tinklas yra suformuotas tiek miestiškų, tiek priemiestinių struktūrų ( 2 pav.). Bendrą senamiesčio plano erdvinių kanalų sistemą, suformuotą istorinio miesto branduolio ir istorinių priemiesčių gatvių bei aikščių bendro tinklo, iliustruoja Vilniaus pavyzdys (3 pav.). 


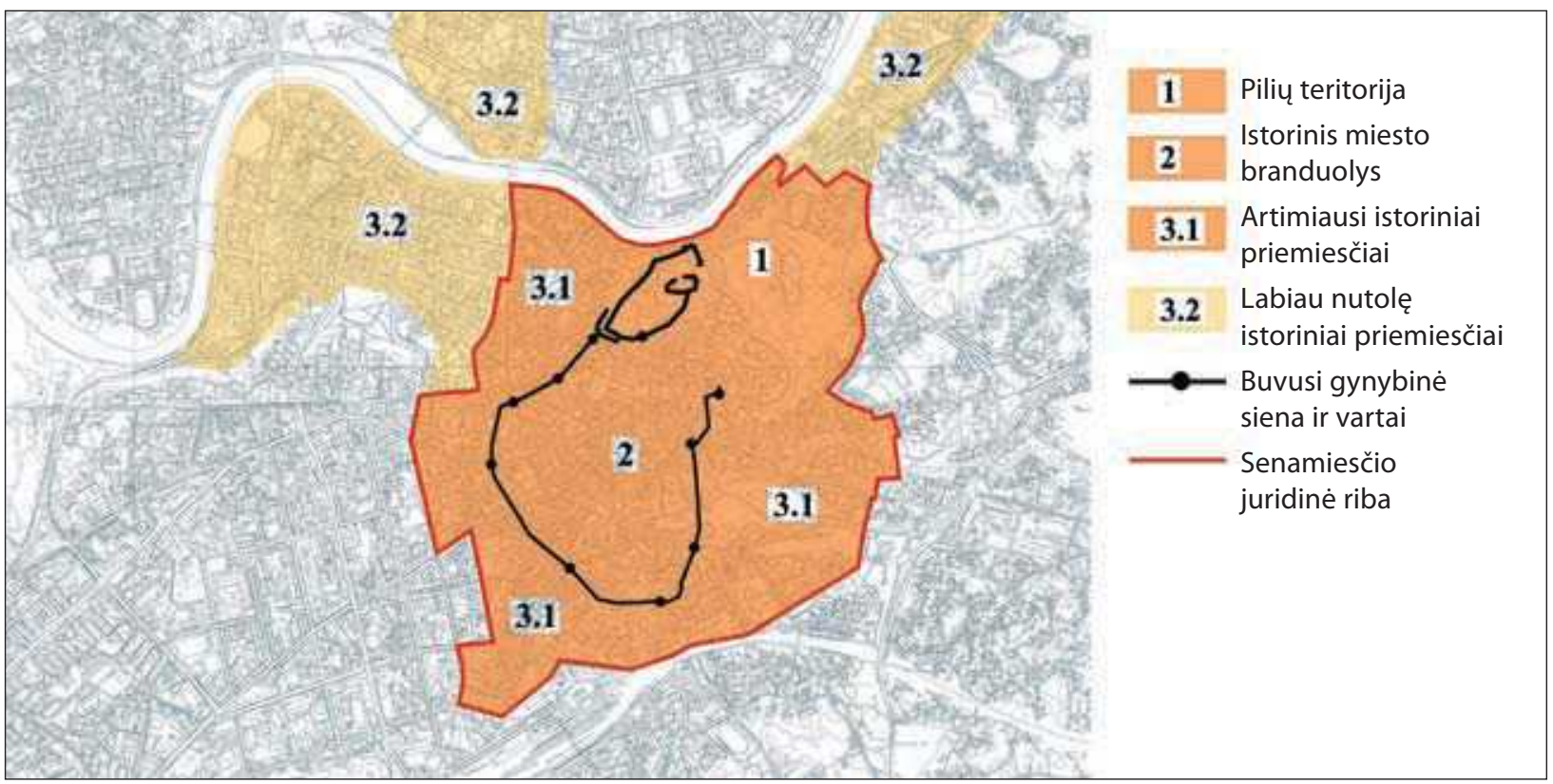

1 pav. Istorinès Vilniaus miesto dalys

Fig 1. Historic parts of Vilnius

2 lentelè. Plano struktūros tipai istoriniuose priemiesčiuose

Table 2. Types of plan structure in historic suburbs

\begin{tabular}{|c|c|c|c|c|}
\hline \multirow{2}{*}{$\begin{array}{l}\text { Plano struktūros } \\
\text { tipas }\end{array}$} & \multicolumn{4}{|c|}{ Istoriniai priemiesčiai } \\
\hline & Vilniuje & Kaune & Klaipèdoje & Kèdainiuose \\
\hline Linijinis & $\begin{array}{l}\text { Aštrusis galas; prie- } \\
\text { miestis už Rūdininkų } \\
\text { vartų; priemiestis už } \\
\text { Trakų vartų; Antakalnis }\end{array}$ & $\begin{array}{l}\text { Linksmadvaris; } \\
\text { Aleksotas }\end{array}$ & Smeltè & - \\
\hline Radialinis & $\begin{array}{l}\text { Užupis; Paplavos; } \\
\text { Šnipiškės (pietinė dalis) }\end{array}$ & Karmelitų priemiestis & - & Skongalis \\
\hline Stačiakampis & $\begin{array}{l}\text { Žvèrynas; Šnipiškès } \\
\text { (šiaurinè dalis) }\end{array}$ & Vilijampolè & Fridricho priemiestis & Jonušava; Knypava \\
\hline Mišrus & $\begin{array}{l}\text { Priemiestis už Vilniaus, } \\
\text { Totorių ir Šlapiujjų } \\
\text { vartų; Lukiškès }\end{array}$ & $\begin{array}{l}\text { Totorių priemiestis; } \\
\text { Freda; Šančiai; Aukštoji } \\
\text { Panemunè }\end{array}$ & Krūmamiestis; Vitès & - \\
\hline
\end{tabular}

Kalbant apie senamiesčių kvartalų ypatumus, reikia pastebėti, kad beveik visų nagrinètų istorinių priemiesčiu kvartalai yra didesni nei istorinio miesto branduolio, tačiau yra ir išimčių (pvz., Vilijampoles Kaune kvartalai netgi mažesni). Kvartalų sistemą nagrinètuose senamiesčiuose iliustruoja 4 pav.

\section{Užstatymo savitumai}

Tirtų senamiesčių branduoliuose vyrauja perimetrinis užstatymo būdas. Istoriniuose priemiesčiuose dažniau- siai sutinkami du morfotipai - tai perimetrinis-posesinis ir sodybinis (šis užstatymo būdas sutinkamas beveik išskirtinai tik istoriniuose priemiesčiuose). Taip pat istoriniuose priemiesčiuose yra ir miesto vilų bei atskirai stovinčių pastatų.

Vilniuje, Kaune, Kèdainiuose vertingi architektūriniai-urbanistiniai statinių kompleksai ir ansambliai yra išsidèstę ne tik istoriniame mieste branduolyje (čia jų koncentracija didesnè), bet ir pasklidę po istorinius priemiesčius. Klaipėdos istoriniuose priemiesčiuose statinių kompleksai ir ansambliai neišliko iki mūsų dienų. 


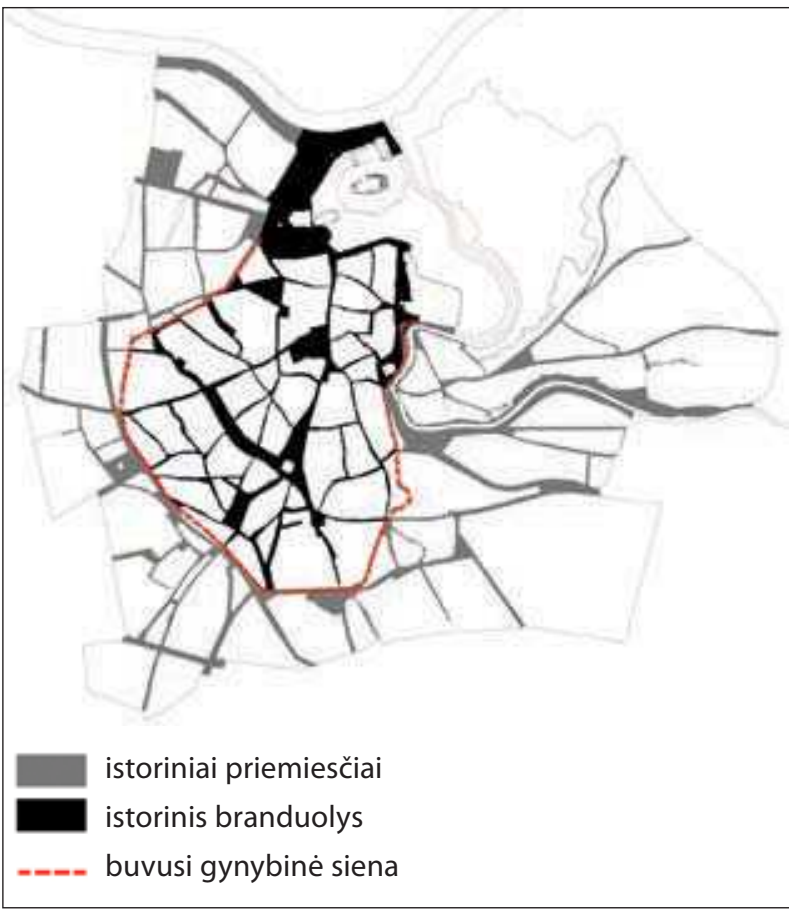

Vilnius

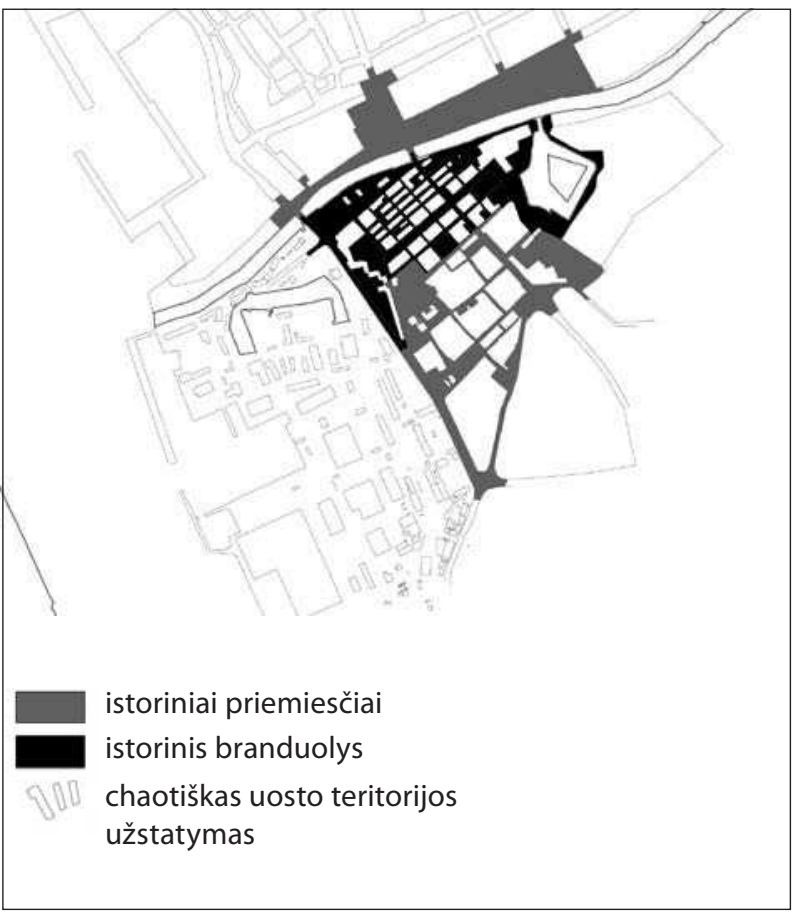

Klaipèda

2 pav. Senamiesčio gatvių ir aikščių tinklas

Figs. 2. Network of streets and squares of old town

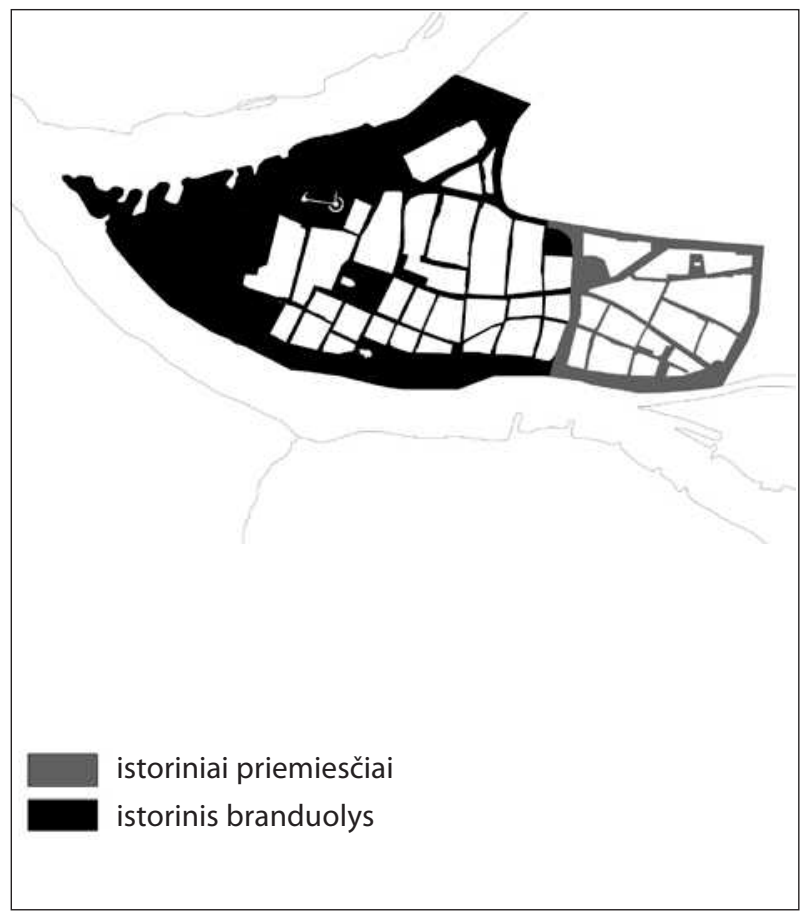

Kaunas

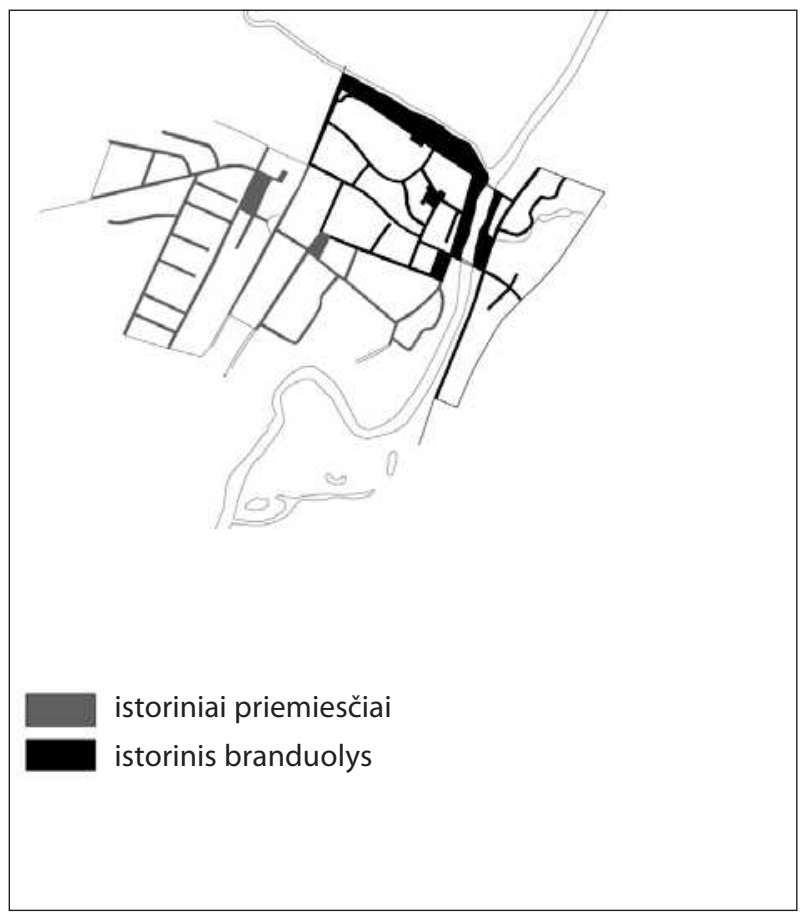

Kèdainiai 


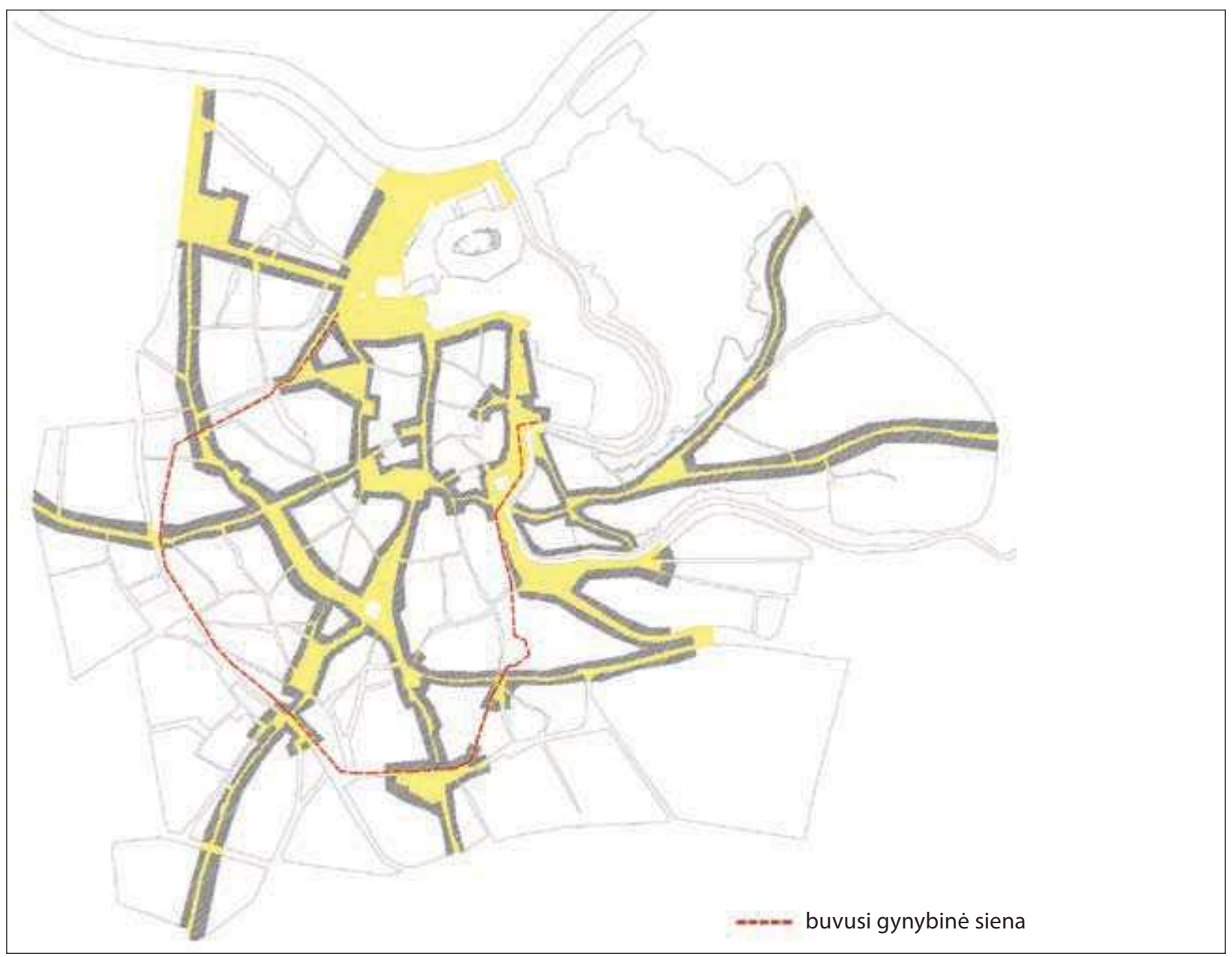

3 pav. Vilniaus senamiesčio plano erdvinių kanalų sistema, suformuota miesto ir priemiesčių gatvių bei aikščių bendro tinklo

Fig. 3. System of spatial channels of Vilnius old town, shaped by the common network of streets and squares of the town and suburbs

Dar viena tirtų senamiesčių užstatymo ypatybė yra išlikusi beveik tik istoriniuose priemiesčiuose - tai sodybiniai sklypai su tradicinès medžio architektūros pastatais. Ilgą laiką priemiesčiuose dominavo medinis užstatymas (nekalbant apie sakralinių statinių ansamblius). Mūrinès statybos atsirado vèliau nei istoriniame miesto branduolyje. Su medžiagine struktūra sietinos tokios istorinių priemiesčių estetinès savybès, kaip morfostruktūros plastiškumas ir dinamiškumas, vaizdų įvairovè ir tapybiškumas (Jurevičienè 2005). Šiuo metu istoriniuose priemiesčiuose vis dar yra medinių namų, statytų XIX-XX amžiuje. Daugiausia tai vienaaukščiai pastatai dvišlaičiais stogais, kartais su mezoninu, balkonais, prieangiais, stogeliais, dekoruoti drožyba (Racevičienè 2006). Daugumos jų būklè yra prasta ir jie gan sparčiai nyksta.

\section{Tūrinės erdvinės kompozicijos savitumai}

Tūrinę erdvinę miesto kompoziciją sudaro daug struktūrinių dèmenų, tačiau šiame straipsnyje yra apsiribojama tik tirtų senamiesčių gamtinių sąlygų, panoramų/ siluetų bei kompozicinių ryšių tarp istorinių priemiesčių ir istorinio miesto branduolio apibūdinimu.

Vilniaus, Kauno, Klaipedos ir Kedainių istorinių centrų gamtinis karkasas yra labai išraiškingas. Gamtiniai barjerai dažną kartą trukdydavo miesto plètrai ir lemdavo istorinių priemiesčių atsiradimą. Iki šių dienų istoriniai priemiesčiai išlaike žalią rūbą - tai labiausiai matoma Vilniuje, kur istorinio miesto branduolio siluetai yra priemiesčio žalių kalvų fone.

Tyrinètų miestų istoriniai priemiesčiai su istoriniu miesto branduoliu susiję labai glaudžiais kompoziciniais ryšiais ir sudaro vientisą urbanistinị kompleksą. 


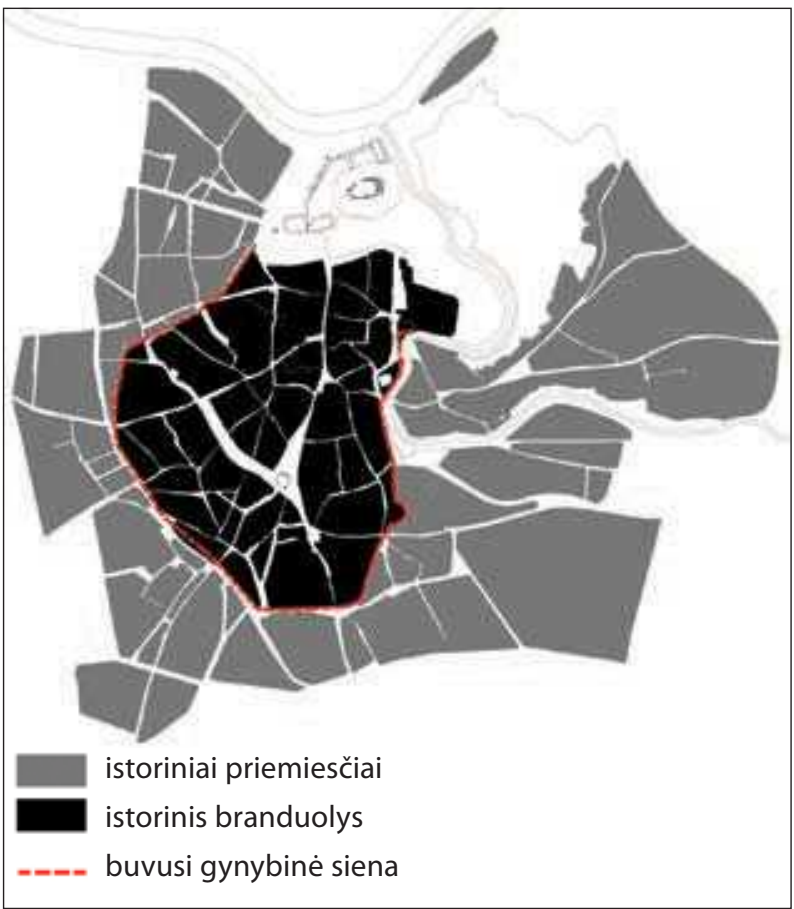

Vilnius

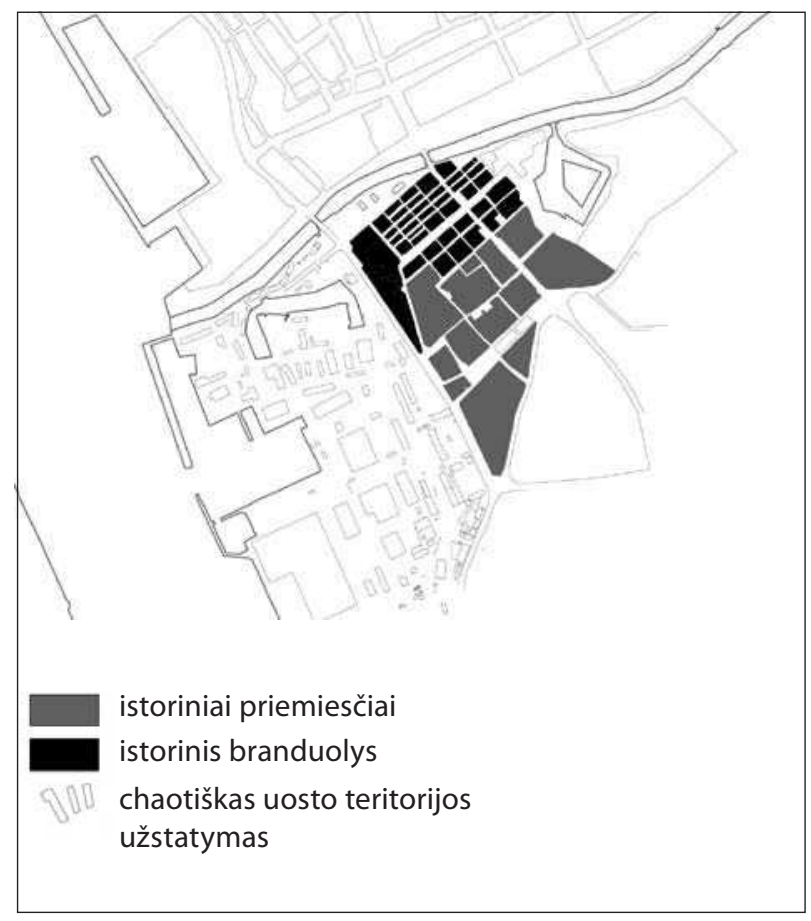

Klaipèda

4 pav. Senamiesčio kvartaly sistema

Fig. 4. System of blocks in old town

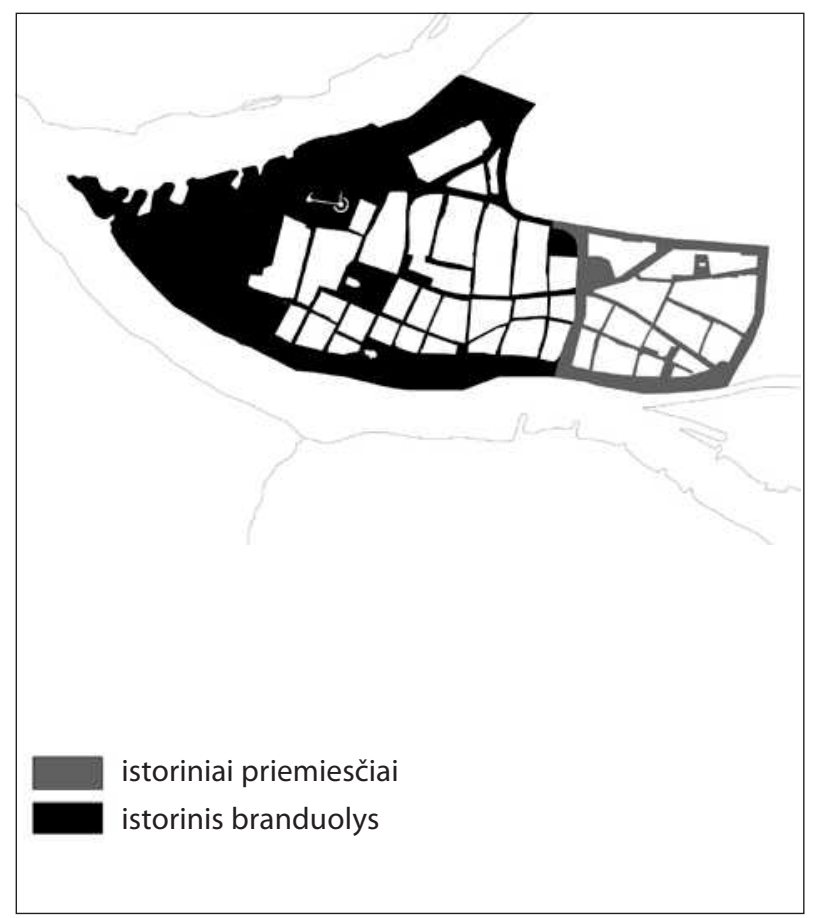

Kaunas

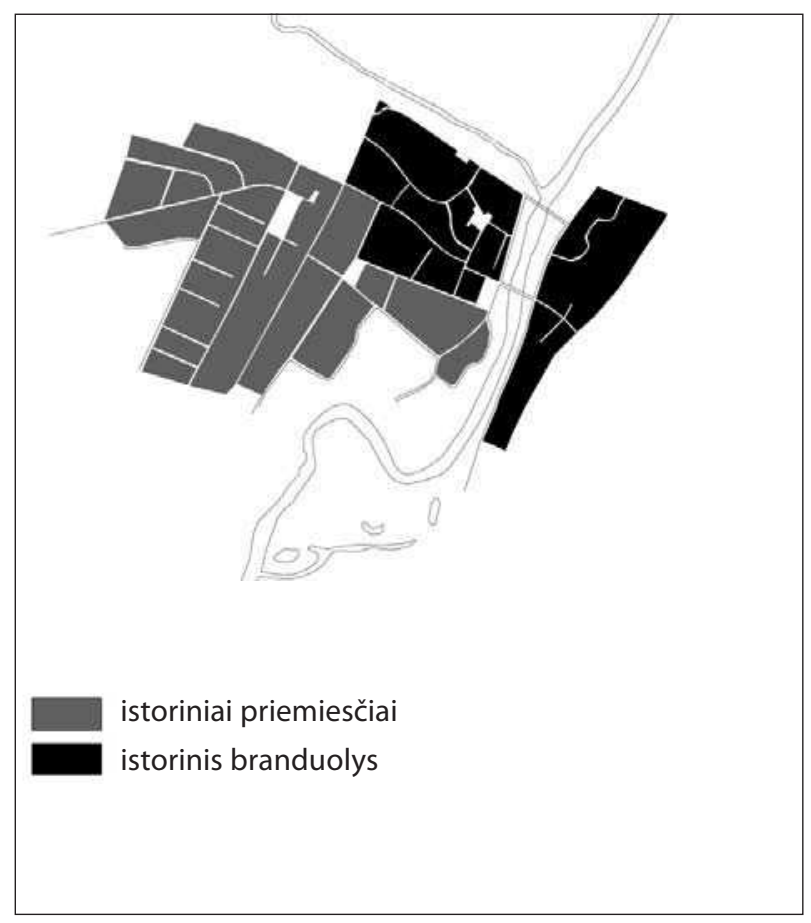

Kèdainiai 


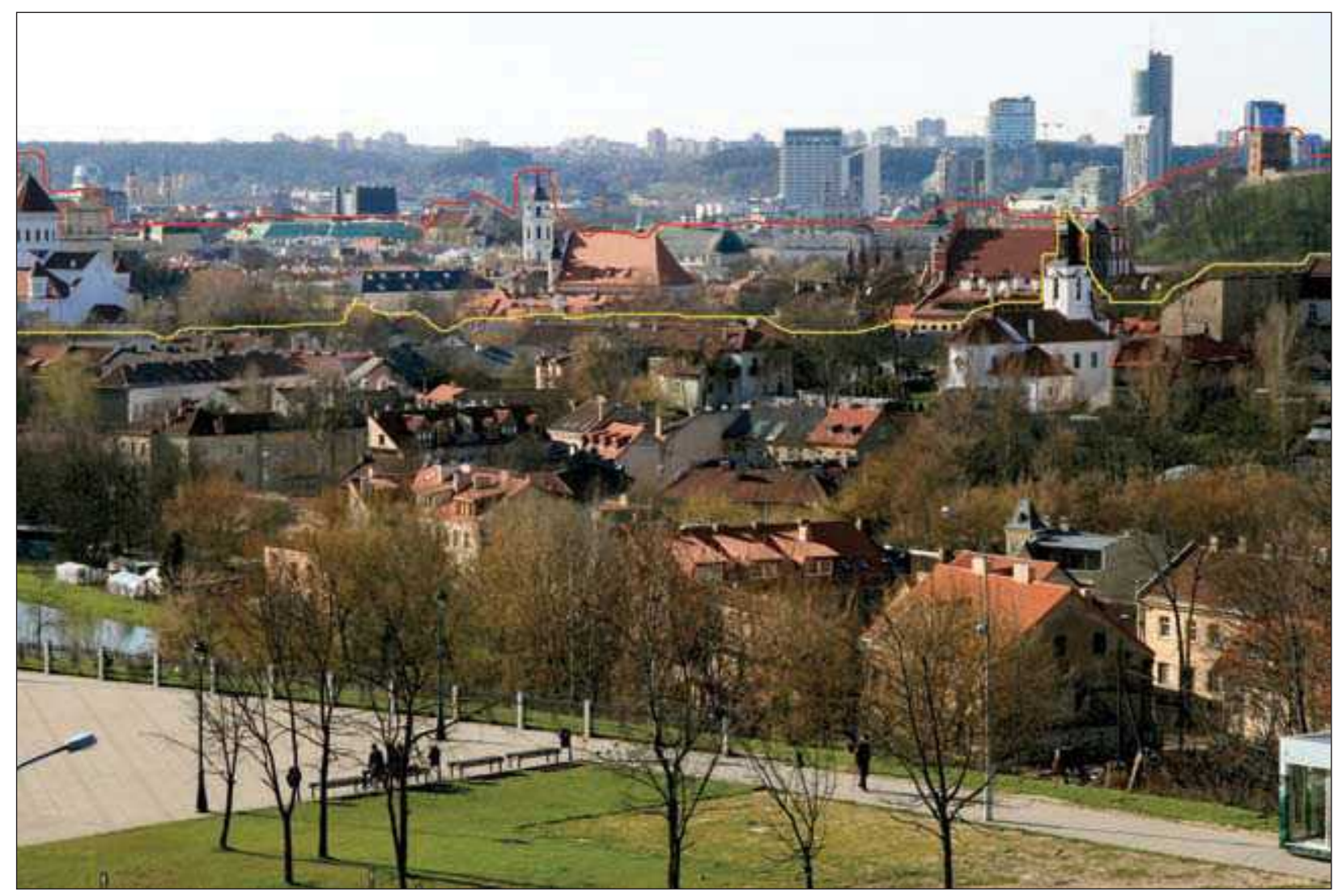

5 pav. Vilniaus senamiesčio panorama, suformuota istorinio miesto branduolio ir istorinio priemiesčio

Fig. 5. Vilnius old town panorama, shaped by the historic town kernel and historic suburb

Nepatyręs stebètojas net nesuprastų, kad senamiesčių panoramas formuoja istoriniai miestų branduoliai ir istoriniai priemiesčiai (5 pav.). Vertikalių dominančių sistema, esanti istoriniuose priemiesčiuose, paįvairina miestovaizdị, suteikdama jam visokių architektūros stilių bruožų. Priemiestinių architektūrinių-urbanistinių statinių kompleksų ir ansamblių vizualinio poveikio laukas apima ne tik priemiesčių teritorijas, bet daro įtaką ir pačių miestų branduolių siluetams.

\section{Apibendrinimas}

Miestų istoriniai centrai išsiskiria ịvaizdžio ir urbanistinès erdvès įvairove, ịgyta šimtmečius trunkančioje miesto urbanistinių struktūrų raidoje. Miesto savitumas ir vizualinis unikalumas yra ypač svarbūs naujojoje globalizacijos eroje, nes yra kultūrinio identiteto sudedamosios dalys (Daunora 2004). Priemiestis, kaip tam tikra urbanistinè struktūra, buvo gana reikšmingas formuojantis daugeliui pasaulio miestų. Ilgainiui kai kurie priemiesčiai ịaugo ị besiplečiančių miestų centrų teritoriją ir prarado ankstesnius savitumus, o kiti tuos savitumus daugiau ar mažiau išlaikè ir papildè istorinių centrų urbanistinę kompoziciją (Dijokienè 2006a). Tokių miestų istorinių centrų urbanistinè kompozicija yra suformuota tiek miesto, tiek ir priemiesčio struktūrų.

Apibendrinant istorinių priemiesčių urbanistinès struktūros komponentus, galima pastebeti, kad:

- stabiliausias nagrinètų urbanistinių struktūrų komponentas yra gatviu tinklas - jis išliko nepakitęs daugelyje istorinių priemiesčių;

- posesine ir kvartalu struktūra, statiniu kompleksai ir ansambliai, gamtiniu salygu ypatumai taip pat išlaike daug autentiškų bruožų;

- užstatymo pobüdis ir panoramos bei siluetai istorijos eigoje kito labiausiai.

Reikètų pabrěžti dar vieną senamiesčių ypatybę ir vertybę - tai kompoziciniai ryšiai tarp istorinio miesto branduolio ir istoriniu priemiesčiu - beveik visuose tirtuose miestuose jie yra labai glaudūs (Dijokiené 2006a). 


\section{Literatūra}

Benevolo, L. 1998. Europos miesto istorija.Vilnius: Baltos lankos, 1998.

Daunora, Z. J. 2004. Istorinių miestų vizualinio įvaizdžio plètojimo klausimu, Urbanistika ir architektūra XXVIII(4): $145-150$.

Dijokienė, D. 2006a. Vilniaus istorinių priemiesčių genezès, raidos ir vertybių ypatumai, Urbanistika ir architektūra XXX(92): 78-86.

Dijokienè, D. 2006b. Lietuvos miestų istorinių priemiesčių genezès, raidos ir vertybių ypatumai (Kaunas, Klaipeda, Kèdainiai), Urbanistika ir architektūra XXX(4): 192-203.

Dijokiené, D. 2007. The impact of historic suburbs on the structural development of cities (based on examples of European cities), Urban heritage: research, interpretation, education, 141-145.

Jurevičienè, J. 2005. Vilniaus istoriniai priemiesčiai: autentiškumo aspektas: daktaro disertacija. Vilnius, VGTU. 118 p.

Kostof, S. 2004. The City Assembled. The Elements of Urban Form through History. London: Thames \& Hudson. 320 p.

Miškinis, A. 2005. Lietuvos urbanistikos paveldas: vertybiu ịteisinimas, apsauga, tvarkymas (1967-1993). Dokumentų rinkinys.Vilnius: Savastis.

Racevičienè, A. A. 2006. Mediniai gyvenamieji namai Vilniuje, Archiforma 1(33): 90-95.

Vilniaus senamiesčio apsaugos reglamentas [interaktyvus]. 2003 [žiūrèta 2008 m. liepos 30 d.]. Prieiga per internetą: $<$ http://www.heritage.lt/vln_regl/index.htm>.

Vyšniūnas, A. 2006. Vilniaus miestas - tarp metaforos ir pragmatikos, Urbanistika ir architektūra XXX(4): 159-176.

\section{HISTORIC SUBURBS IN THE STRUCTURE OF OLD TOWNS}

\section{Dijokienè}

Abstract. Attention is drawn to the fact that the borders of majority of protected old towns in Lithuania are juridical rather than structural. This complicates protection of these territories. The following concepts are defined: historic town, old town, historic kernel of town, historic suburb. Urban characteristics (plan, buildup, size-and-space composition) of the historic suburbs of Vilnius, Kaunas, Klaipeda and Kedainiai that are within the borders of the old towns are described in a summarized way. The components of the old towns (historic town's kernel and historic suburbs) are distinguished in the illustrating material.

Keywords: historic town, historic suburb, old town, historic kernel of town, urban heritage, cultural heritage.

\section{DALIA DIJOKIENE்}

Doctor of the Humanities (arch), Assoc Prof, Dept of Urban Design, Vilnius Gediminas Technical University, Pylimo g. 26/Traku. g. 1, LT-01132Vilnius, Lithuania.E-mail:dijokai@takas.lt

Teaching: lectures on architectural design. Conferences: reports at 4 international, 6 national conferences. Projects: author or co-author of more than 30 projects of architectural design and planning. Research interests: urban nuances of the town spatial expansion beyond the old town's borders. 